\title{
The Roles of English Language and Imagined Communities of a Facebook Group
}

\author{
http://dx.doi.org/10.3991/ijet.v10i6.4831 \\ Latisha Asmaak Shafie ${ }^{1}$, Aizan Yaacob ${ }^{2}$ and Paramjit Kaur A/P Karpal Singh ${ }^{2}$ \\ ${ }^{1}$ Universiti Teknologi Mara Perlis, Arau, Malaysia \\ ${ }^{2}$ Universiti Utara Malaysia, Sintok, Malaysia
}

\begin{abstract}
Social network sites are the networked public places for university students. The most famous social network site in Malaysia for university students is Facebook. University students spend a lot of their time navigating collapsed contexts with global and local audience. Thus, Facebook is the most appropriate site to investigate ESL learning acquisition through $L 2$ learners' interactions and digital footprints. The study investigates the roles of English language and the types of imagined communities of ten $L 2$ learners at a public university. Transcripts of a Facebook group's online discussion and semi-structured interviews were analysed using qualitative data software Atlas.ti 7. The findings reveal that the key informants are invested to learn English due to its roles in Malaysia. English language has four dominant roles such as the language for their future employment, the language of instruction, the lingua franca and a tool of empowerment. The research also indicates the imagined communities of the key participants are fluent local speakers, fluent non-native speakers and native speakers. The results of the study provide present needs of ESL learners that will enable insights to language instructors, course designers and curriculum designers in facilitating effective language acquisition. instructions give you basic guidelines for preparing camera-ready papers for conference proceedings. Use this document as a template if you are using Microsoft Word 6.0 or later. Otherwise, use this document as an instruction set. The electronic file of your paper will be formatted further. Define all symbols used in the abstract. Do not cite references in the abstract.
\end{abstract}

Index Terms - identity, investment, second language learning, social network sites,

\section{INTRODUCTION}

In multi-cultural postcolonial site Malaysia, L2 learners struggle to gain entry to communities of non-native and native speakers of the target language. In addition, L2 learners face struggles to practise their language proficiency from their home community members. Digital natives were born after 1980 and are constantly connected to their peers through technology tools (Prensky, 2001). Thinking and learning for digital learners is defined and shaped by technology. Digital learners expect learning as active, interesting and instant gratification activities. However, educators often forget to take account of the digital natives' rich lives outside of classrooms. In classrooms, these learners write for academic purposes with their lecturers and their friends as the audience. Considering that outside of classrooms, they assume the roles of virtual entrepreneurs, bloggers, expert gamers or active members of online communities are intellectually contrib- uting and exchanging opinions with members of their communities. It is only wise for universities to study how digital natives learn as the majority of their current students are digital natives.

Web 2.0 technology tools influence students to be coproducers of their own content as information is constantly improved, shared and created. Web 2.0 technologies encourage collaboration, interactivity and involvement of online communities in knowledge construction environment of university students as the Internet is a ubiquitous tool for university students. Web 3.0 is moving to personalization of the Internet and web applications to the users. Soon university students will be able to have their personalized information.

\section{LITERATURE REVIEW}

Currently, university students use social network sites to communicate. Social network sites are web-based services that allow users to construct a public or private profile within a system, a list of users' friends and a view of their list of connections and those made by others within that system (boyd and Ellison, 2007). Social network sites began to be popular with Friendster, MySpace and Facebook. Facebook is the most popular social network sites with university students in Malaysia. Popularity of social network sites sparks studies on asynchronous and synchronous computer-mediated discourse. Social network sites are considered as a Web 2.0 technology with a potential for language learning purposes (Carroll, 2008; Latisha Asmaak Shafie \& Surina Nayan, 2013). Web 2.0 applications are appropriate for language learning as the applications require integrations of language skills such as listening, reading, speaking and writing through user-generated content and forms of publication (Warschuer, 2009). In addition, Web 2.0 requires students to handle cognitive and social processes such as identity formation, critical literacy and information overload. Ching and Hsu (2010) emphasize that higher education still do not fully utilised the benefits of Web 2.0 technology tools as interactive participatory social aspect of Web 2.0 is missing from learning. Kelley (2010) proposes networked public places such as social network sites are this century 'gathering places' which are untapped area for EFL students as there many groups doing many kinds of activities at different levels together. Blattner and Fiori (2009) argue Facebook improves authentic language interaction, increase motivation and improve language performance. English language teaching and learning in Malaysia does not often use Facebook applications (Kamarul Kabilan, Norlida Ahmad \& Zainol Abidin, 2010; Melor, 2007; Melor Md Yunus, Hadi Salehi \& Chen Chenzi, 2012, Nazatul Aini, 2014). 
PAPER

The Roles of English LANGUAGE AND IMAGINED COMMUNITIES OF A FACEBOOK GROUP

Investment describes students' participation and nonparticipation in their second language learning activities. Investment is a sociological construct. Learners commit to their language learning if they are invested in acquiring the target language (Norton, 2002). Learners are invested in learning English for several reasons. There are four categories of investment in language learning such as cultural capital, economic capital, social capital and symbolic capital (Bourdieu, 1986). Cultural capital such as accent, appropriate behaviour and connections to access to desired networks is an enabler to other categories of investment. Social capital is generated through connections of families, social connections and social networks. Economic capital encompasses of inherited or generated wealth through individuals and the economy. Symbolic capital is an individual's prestige and personal qualities (Block, 2007).

Investment is a framework that enables further understanding in motivation to learn a language (Norton, 1995, 2001). Investment in a particular identity influences relationship to the target language and target language group (Norton Peirce, 1995). Individuals align themselves with their imagined communities when they participate in the practices of the communities (Norton, 2001). Norton argues there is an integral relationship between learners' investment and identity as learners' investment in learning a language is associated with a learner's commitment to learning. In Canada, Norton (2003) finds young readers invested in learning the language by reading Archie comics although they receive less validation from their parents. Participants in Uganda and Pakistan indicated their imagined community is of an English-speaking community with social, economic and political resources. Afghan refugee children in the Youth Millennium Project in Karachi are invested in learning English as English is perceived as the language of development, science and technology (Norton \& Kamal, 2003). The findings indicate Muslim students do not associate with religious and linguistic affiliations when they learn English. These students identify English speakers as educated people in a developed country with resources and these speakers become their imagined communities. Similarly, Norton and Williams (2012) find that learners in a poorly resourced community invest in learning technology in eGranary project to gain cultural capital, economic capital, social capital and symbolic capital.

However, resistance to the language was projected in many postcolonial sites. Lee Su Kin (2001, 2003, 2005, 2006) in a study of attitude of Malay postgraduates towards English indicated that the participants perceived learning English as being show off, boastful, elitist, betrayal of Malay cultural and identity. This finding is supported by another research which comprised of Chinese participants that show the participants were regarded as being too westernized for being fluent in English (Lee Su Kim, 2006, Lee Su Kim et al 2007). However, the study of multilingual Malaysian undergraduates at private and public universities in Malaysia indicated there was a shift in attitude among these graduates as they embrace English as their own language to project their own voices not as a second language (Lee Su Kim et al, 2010).

Rajadurai (2009) investigated a group of Malay learners who were teacher trainees and students of Teaching of English as a Second Language (TESL) in Malaysia to comprehend the process of adult second language learning in non-native countries. These Malay TESL students admitted they needed safe learning environments just like 'safe houses' (Canagarajah, 1997). These students faced less support, as mastering English endangers language and culture by their societies at home. There was a struggle between being Malays and learning English as English was the language of the colonialists. Rajadurai(2009) perceived learning English as a second language as a process of identity negotiation and struggle for participation, acceptance and legitimacy. Ratnawati (2005) indicated Malays were reluctant to learn English due to cultural and religious identity. Malays are identified as people who practice Islam, Malay culture and Bahasa Melayu.

Norton (2001) describes imagined communities as communities that language learners associate with, to which their existence is not a certainty. The desire to belong to these groups encourages and motivates the learners to invest in language learning activities. Learners are invested to join this imagined community. Murphey, Chen and Chen (2005) point out when learners want to join their imagined communities; time and energy are spent on learning to be like their members. A study conducted by Gao, Cheng and Kelly (2008) of a weekly English discussion group in English Club by groups of students in Hong Kong reveal a different imagined community. Chinese students were attracted to this club as this club provided them supportive English speaking environment to speak sensitive issue. They were able to improve their spoken skills, had a sense of ownership and projected their plans. Learning English is not associated with either the target language culture or the native speakers but an imagined community of Elite Chinese who are fluent speakers of English.

\section{THEORETICAL BACKGROUND}

\section{A. Identity Approach}

Mainstream theories of second language acquisition concentrate on cognitive capacities and experimentally oriented as language learning is seen as individualised and autonomous process rather than social interactions among interlocutors. In conducting this research, the study adopts an identity approach to second language acquisition introduced by Norton and McKinney (2011). Norton (1995, 2000) employs Bourdieu's construct of investment (1991) as a sociological construct to describe L2 learners' commitment to language learning as replacement for motivation. The second construct of identity approach is imagined communities that are defined as communities that are not yet tangible and accessible with whom learners affiliate with (Norton, 2000). These imagined communities can be powerful in making L2 learners participate in language learning activities. These two constructs interact in which the constructs are critical success factors for L2 learning. The study uses identity approach to second language acquisition as it focuses on sociological and historical aspects of language learning.

Identity approach to second language acquisition is based on poststructuralist theories, which propagates language learning is not an individualised internalised process of set of rules, vocabulary and structures of a language (Norton \& McKinney, 2011). Societies are seen as sites of struggles, and linguistic communities are heterogeneous with conflicted power and claims to truth. Poststructuralist theorists draw attention to L2 learners as 
PAPER

The Roles of ENGLish LANGUAGE AND IMAGINED COMMUNITIES OF A FACEBOOK GROUP

diverse, contradictory, heterogeneous, charismatic and inconstant over time and space (Bakhtin, 1981; Bourdieu, 1984; Weedon, 1997). The key informants belong to diverse heterogeneous online, and offline communities impregnate with conflicts and social tension with English as the target language. In addition, on Facebook, the key informants face local and global audience at the same time. The online interactions with their multiple audiences reveal their investment in L2 learning and imagined communities.

\section{RESEARCH Methodology}

The study employs a qualitative case study as to investigate ten key informants of Malay ethnicity in Malaysia. A case study design is employed to understand L2 learners' investment and imagined communities. A case study allows researchers to examine the phenomena in real-life contexts. Researchers conduct a holistic and in-depth investigation by examining data within a context. According to Merriam (2001), case study focuses on the process, the context and the discovery. A case study allows researchers to observe and analyse key informants' actions and behaviors within authentic contexts.

Case study design allows researchers to capture rich subtle and complex explanations from a variety of data sources like interviews, observations and document analysis (Cohen, Manion \& Morrison, 2000; Merriam, 2001; Johnson, 2005). The study employs a specific bounded case to allow the researcher to investigate contextual factors to understand the phenomena. This study is known as interpretive case study. In interpretive case studies, researchers categorise concepts from the data to support or reject assumptions made about the phenomena before the data collection (Merriam, 1998). In interpretive case studies, data is interpreted through conceptual categories to enable researchers to contemplate the phenomena studied through the perspectives of the participants. Interpretive case studies emphasise on the social construction of reality of the participants in order to explain the reasons and the ways participants perceive the phenomena.

This study addressed the reasons for L2 learners' investment in learning English language and L2 learners' imagined communities. Data was collected from ten L2 learners who were university students of a local university. The research tools employed in this study were observation, an analysis of online discussions of a Facebook secret group and e-mail interviews. The research was a part of a larger project. Only results regarding investment and imagined communities are analysed. Intra-coder reliability was established by re-coding the transcripts after a lapse of a month. Member checking and peer debriefing were used for reliability. Data was analysed using qualitative software data analysis, Atlas.ti 7 using inductive data reduction analysis.

\section{PARTICIPANTS AND SETTINGS}

The key informants were students of a public university in Malaysia. The key informants volunteered to participate in an online Facebook group after the researchers advertised using their Facebook accounts. There were 179 members of an online language community. The group is a Facebook group and created for the research. All the members were students at the public university. The key informants were the most active members of the online language community. They were active as they wanted more opportunities to practice their language proficiency. There were eight female key informants and two male key informants. Their ages ranged from 19 to 24 years old. Ten key informants are identified as Participant A, B, C, D, E, F, G, H, I and J. The study was carried out from January 2014 to March 2014. The researchers posted the topics to be discussed in the Facebook group. The online discussion addressed issues about second language learning. The key informants commented on the topics and other key informants' responses. The key informants were allowed to respond to the online discussion within the stipulated timeframe. In addition, e-mail interviews were conducted for each key informant. The key informants were interviewed on language issues and their language learning experiences. The interviews were conducted using e-mails as the key informants were located in different states in Malaysia as they are students at various branches of a public university in Malaysia.

\section{FINDINGS AND Discussion}

The section discusses L2 learners' investment in their English language learning and their imagined communities. Firstly, the section discusses L2 learners' investment in learning English language. Secondly, the study explains about L2 learners' imagined communities. Examination of L2 learners' investment and imagined communities reveal complexities of learning a second language in non-native settings in a postcolonial setting.

The key informants perceive that English is a powerful language. The findings reveal there are four significant themes such as English for workplace purposes, English as a lingua franca, English as the tool for empowerment and English as language instruction. English is seen as an investment for the future. These four roles of English language in Malaysia explain the reasons key informants are invested in learning English language.

The first emerging trend is that the key informants perceive English for workplace purposes. The key informants believe that mastering English would be a key to a better future with better work opportunities. As a result, the key participants in the study are invested in learning English in order to secure better employment. The finding is similar to studies conducted in postcolonial sites (Norton \& Mutonyi, 2007; Norton \& Kamal, 2003; Norton \& Williams, 2012; Pavlenko \& Norton, 2007).

Excerpt 1: Well, I take it as an opportunity. This will give me an opportunity to grab the chance for more choices of career. Organizations are competing out there with each other to hired well communicate employees especially in English. Opportunity for a better life. (Participant A)

Excerpt 2: In my opinion, learning English is an opportunity to us,because when we learn English we have an advantage to compete with others to get a job in the future. Many company are hire people based on the ability of student to speak in english not the cgpa.(Participant D)

The second role of English is as a lingua franca. The key informants in this study are aware that they have more choices in being global citizens. They have opportunities for working or studying abroad. It is common for Malaysians to travel for leisure and work to foreign shores. English is a lingua franca that enables people to communicate even when there are many dominating languages such as French, Spanish, Arabic and Mandarin. It can be conclud- 
ed that the participants feel it is a necessity to master English as they need the language to communicate with other people once they travel to foreign soils.

Excerpt 3: The English language is the most widely spoken language in the world and the predominant academic language around the world (Participant G)

Excerpt 4: for easiest communication, English language is used as it is widely used in many countries around the world. so it is important for the community in a country to be good in English in order to adapt with the globalisation. they cannot use their local language as other people from other countries cannot understand it so the safest way is to use English language (Participant B)

The third significant theme is English is seen as a tool for empowerment. English language empowers female key informants. English is not just a language as the language has given them a voice to be heard. Female key informants believe they have the respect they crave badly when they communicate in English. Malay society is a patriarchy society. It could be as being Malay young women who are surrounded in a patriarch society, they feel that their voice in their native language is not being heard.

Excerpt 5: so it's good to learn English as it makes people respect you. (Participant $\mathrm{H}$ )

Excerpt 6: Malaysians are producing credible workers and managers. You can earn respect when u use English.( Participant A)

The fourth significant theme is English is perceived as a language of instruction. The university where the key informants study uses English as the language of instruction. In other word, the key informants learn their subjects in English. The tests, assignments and examinations are in English. For this reason, it is not surprising that the key informants invest in mastering English as high proficiency in English fulfills their current needs as undergraduates.

Excerpt 7: most text books that my lecturer recommended are all written in English..and $\mathrm{i}$ get to learn new things from the books that $\mathrm{i}$ read... the language used in teaching is English..thus students must have knowledge about English so that they will not left behind in class.. (Participant E)

Excerpt 8: I tried to learn English language since almost all the subjects are in English (Participant J)

Imagined Communities of the key informants were also analysed. The findings indicate that the majority of the key informants have non-native speakers as their imagined communities. The most significant theme is local nonnative speakers. Most key informants confess that their imagined communities consist of local non-native speakers who are fluent speakers of English. The key informants reveal that many non-native speakers can master the language. It is concluded that their imagined communities consist of fluent speakers of English from Malaysians. The reasons given are they are more comfortable with non-native speakers as it is easier to understand non-native speakers due to accents and the possibility of codeswitching when situation arises. Another explanation is that the key informants might lack confidence to communicate in English with native speakers.
Excerpt 9: I prefer to communicate English with nonnative speakers like Malaysians... because if I speak, they can understand easily what $i$ want to convey to them... as our English in terms of pronunciations is not so much different. I think communicate with native speakers such as Americans, British would be a little bit difficult. It is because their slang is different from us. There might be certain words that they said that I, maybe not understand and cannot guess the meaning.(Participant B)

Excerpt 10: i prefer speaking with Malaysians (Participant E)

The second significant theme is global non-native speakers of English. The key informants associate with global non-native speakers of English. These key informants perceive English as the language for everyone who could master it. The key informants might have communicated with other non-native speakers in English and realise there is an abundance of opportunities to communicate with non-native speakers rather than native speakers.

Excerpt 11: i define a fluent speaker of English language as someone who can speak confidently in proper/standard English..no silly grammatical errors..excellent pronunciation..don't need to arrange words from native language to English language during conversation..he/she speaks English as if he/she speaks his/her native language..everything that is said can be understood by the listeners. (Participant E)

Excerpt 12: I don't mind..as long as we can understand each other..either native or non-native speakers have their own dialects and make the communication to be more fun (Participant J)

The third significant theme emerges from the data shows native speakers are imagined communities of only one key informant. Participant A, expresses her dream to be able to be a part of a community of native speakers. She believes that she has already had enough practices communicating with non-native speakers. Participant A feels she will be considered as a fluent speaker if she is as articulate as native speakers. Participant A wants to join a community of native speakers so she has many opportunities communicating with native speakers of English.

Excerpt 13: I prefer to communicate with native speakers. This is because, when I try to communicate with them, I will push myself harder to speak English in the right/proper way to look good. (Participant A)

\section{CONCLUSION}

The ubiquity of the Internet causes globalization to be at the tip of one's finger. L2 learners are constantly connected to their global and local audience as they navigate their social network sites. It is obvious that participants invest in learning English because of the language's four dominant roles. The most dominant theme is learning English for occupational purposes. The key informants believe high proficiency in English is the key to securing employment. Just like other studies in imagined communities (Gao, 2007), the participants' imagined communities consist of locals who are fluent English speakers. The findings of the study provide insights on the needs of the present L2 learners at tertiary level to language instructors, curriculum designers and policy makers in order to facilitate their learning acquisition of English language. 


\section{REFERENCES}

[1] Anderson, B. (1991). Imagined communities: reflections on the origin and spread of nationalism. New York:

[2] Andrew, M. \& Romova, Z. (2012). Genre, discourse and imagined communities: the learning gains of academic writing learners. Journal of Academic Language and Learning, 6 (1), A77-A88.

[3] Bakhtin,M. (1981). The dialogic imagination: Four essays by M.M. Bakhtin. Austin, TX: University of Texas Press.

[4] Blattner, G., \& Fiori, M. (2011). Virtual social network communities: An investigation of language learners' development of sociopragmatic awareness and multiliteracy skills. CALICO Journal, 29(1), 24-43. http://dx.doi.org/10.11139/cj.29.1.24-43

[5] Block, D. (2007). Second language identities. London \& New York: Continuum.

[6] Bourdieu,P. (1991). Language and symbolic of power. Cambridge: Polity Press.

[7] Bourdieu,P. (1984). Distinction : A social critique of the judgement of taste (R. Nice, Trans.). London: Routledge \& Kegan Paul.

[8] Bourdieu, P. (1986). The forms of capital. In J. Richardson (Ed.), Handbook of theory and research for the sociology of education (pp. 241-258). New York: Greenwood Press.

[9] boyd, d. (2006). Friends, Friendster, and Top 8: Writing community into being on social network sites. First Monday , 11 (12), 1-14. Retrieved March 23, 2010 from http:// firstmonday.org/htbin/cgiwrap/bin/ojs/index.php/fm/article/view/1 418/1336 http://dx.doi.org/10.5210/fm.v11i12.1418

[10] boyd, d., \& Ellison, N. (2007). Social network sites: Definition, history, and scholarship. Journal of Computer-Mediated Communication, 13(1), 210-230. http://dx.doi.org/10.1111/j.10836101.2007.00393.x

[11] Canagarajah, A.S. (1997). Safe houses in the contact zone: Coping strategies of African American students in the academy. College Composition and Communication, 48(2):173-96. http://dx.doi.org/10.2307/358665

[12] Carrol,K. (2008). Skype, social networks and learning. Retrieved from http://ken-carroll.com/2008/01/14/skype-social-networksand-language-learning

[13] Ching, Y.H. \& Hsu, Y.C. (2010). Blogging in higher education: Issues, challenges, and design considerations. Proceedings of Association for Educational Communications and Technology (AECT) Annual International Convention October 27-30. Anaheim, California.

[14] Gao, X., Cheng, H., \& Kelly, P. (2008). Supplementing an uncertain investment? Mainland Chinese students practicing English together in Hong Kong. Journal of Asian Pacific Communication, 18 (1), 9-29. http://dx.doi.org/10.1075/japc.18.1.02gao

[15] Gao, Y. (2007). Legitimacy of foreign language learning and identity research: Structuralist and constructivist perspectives. Intercultural Communication Studies, 16 (1), 100-112.

[16] Gao, Y., Cheng, Y., Zhao, Y., \& Zhou, Y. (2005). Self-identity changes and English learning among Chinese undergraduates. World Englishes, 24 (1), 39-51. http://dx.doi.org/10.1111/j.08832919.2005.00386.x

[17] Gao Y., \& Xiu L. (2008). We could be heroes just for one day: Investment in English songs and movies and construction of multiple identities. CELEA Journal, 31 (4), 93-101.

[18] Gu,M.(2008).Identity construction and investment transformation: College students from non-urban areas in China. Journal of Asian Pacific Communication, 18 (1), 49-70. http://dx.doi.org/10.1075/ japc.18.1.04gu

[19] Gee, J.P. (2010). How to do Discourse Analysis: A Toolkit. New York : Routledge

[20] Halvorsen, A. (2009). Social networking and critical language learning. In M. Thomas, (Ed.), Handbook of research on Web 2.0 and second language learning (pp. 237-258). Hershey, PA: IGI Global. http://dx.doi.org/10.4018/978-1-60566-190-2.ch013

[21] Kabilan, M. K., Ahmad, N., \& Zainol Abidin, M. J. (2010). Facebook: An online environment for learning of English in institutions of higher education? Internet and Higher Education, 13(4), 179-187. http://dx.doi.org/10.1016/j.iheduc.2010.07.003

[22] Kanno, Y. \& Norton, B. (2003). Imagined communities and educational possibilities: Introduction. Journal of Language, Iden- tity, and Education, 2 (4), 241-249. http://dx.doi.org/10.1207/ $\underline{\text { S15327701JLIE0204_1 }}$

[23] Kelly, J. A. (2010). Social network sites and the ideal L2 self: Using MySpace in a Chinese EFL class. The JALT CALL Journal, 6(1), 17-33.

[24] Latisha Asmaak Shafie, Surina Nayan and Nazira Osman. (2012). Constructing Identity through Facebook profiles: Online Identity and Visual Impression Management of University Students in Malaysia, Procedia- Social and Behavioural Sciences, Volume 65, 130-140. http://dx.doi.org/10.1016/j.sbspro.2012.11.102

[25] Latisha Asmaak Shafie, Mahani Mansor, Nazira Osman, Surina Nayan and Anis Maesin.(2011). Privacy, Trust and Social Network Sites of University Students in Malaysia. Research Journal of International Studies, Issue 8, 1-9.

[26] Latisha Asmaak Shafie and Surina Nayan. (2013). Languages, Code-switching Practice and Primary Functionsof Facebook among University Students. Study in English Language Teaching, 1(1), 187-199.

[27] Lee, S. \& Chung Hyun, L. (2013). A case study on the effects of an 12 writing instructional model for blended learning in higher education. The Turkish Online Journal of Educational Technology October 2013, Vol.12 (4).

[28] Lee Su Kim . (2001). A qualitative study of the impact of the English language on the construction of the sociocultural identities of ESL speakers. (Doctoral dissertation). Retrieved from ProQuest Dissertations and Theses database (AAT3003153).

[29] Lee, Su Kim. (2003) Multiple identities in a multicultural world: A Malaysian perspective. Journal of Language, Identity and Education, 2(3), 137- 158. $\quad$ http://dx.doi.org/10.1207/S1532770 1JLIE0203_1

[30] Lee, Su Kim. (2003). Entrapment or empowerment: ESL profiles. Journal of Language Teaching, Linguistics and Literature, 8 ,2839.

[31] Lee, Su Kim.(2003). Exploring the relationship between language, culture and identity, GEMA Online Journal, 3(2).Retrieved from http://journalarticle.ukm.my/731/1/GemaVol3.1.2003No3.pdf

[32] Lee, Su Kim. (2004). Colonial imposition or linguistic empowerment? Voices from the outer circle. International Journal of the Humanities, 2, 734-741.

[33] Lee Su Kim. (2006). Masking: Maneuvers of skilled ESL speakers in postcolonial societies. In Azirah Hashim and Norizah Hassan (Eds.), English in South East Asia: Prospects, Perspectives and Possibilities. Kuala Lumpur: University of Malaya Press.

[34] Lee Su Kim, Thang Siew Ming, \& Lee King Siong. (2007). Border crossings: Moving across languages and cultural frameworks. Kuala Lumpur: Pelanduk Publications.

[35] Lee Su Kim, Lee King Siong, Wong Fook Fei, \& Azizah Ya'acob.(2010). The English Language and its impact on identities of multilingual Malaysian undergraduates. GEMA: Online Journal of Language Studies, 10 (1), 87-101.

[36] Melor Md Yunus, Hadi Salehi \& Chen Chenzi. (2012).Integrating social networking tools into ESL writing classroom: Strengths and weaknesses. English Language Teaching, 5(8), 42-48. doi:10.5539/elt.v5n8p42 http://dx.doi.org/10.5539/elt.v5n8p42

[37] Merriam,S. B. (1998). Qualitative research and case study applications in education. San Francisco: Jossey-Bass.

[38] Merriam,S.B. (2001). Qualitative research and case study applications in education: Revised and expanded from case study research in education. San Francisco: Jossey- Bass.

[39] Murphey,T., Chen,J., \& Chen,L. ( 2005). Learners' constructions of identities and imagined communities. In P. Benson \& D. Nunans (Eds.), Learners' stories (pp. 83-100).Cambridge : Cambridge University Press.

[40] Nazatul Aini Abd. Majid. (2014). Integration Of Web 2.0 Tools In Learning A Programming Course. The Turkish Online Journal of Educational Technology October 2014,Vol.13 (4).

[41] Norton Peirce, B. (1995). Social identity, investment, and language learning. TESOL Quarterly, 29 (1), 31.

[42] Norton, B. (2001) Non-participation, imagined communities, and the language classroom. In M. Breen,(Ed.) Learner contributions to language learning: New directions in research (pp.159-171) Harlow England: Pearson Education. 
PAPER

The Roles of ENGLish LANGUAGE AND IMAGINED COMMUNITIES OF A FACEBOOK GROUP

[43] Norton, B. (2003). The motivating power of comic books: Insights from Archie Comic Readers. The Reading Teacher, 57(2), 140147.

[44] Norton, B., \& Gao, Y. (2008). Identity, investment, and Chinese learners of English. Journal of Asian Pacific Communication, 18 (1), 109-120. http://dx.doi.org/10.1075/japc.18.1.07nor

[45] Norton, B., \& Kamal, F.(2003). The imagined communities of English language learners in a Pakistani school.Journal of Language, Identity, and Education, 2(4), 301-307. http://dx.doi.org/10.1207/S15327701JLIE0204_5

[46] Norton, B., \& McKinney, C. (2011). An Identity Approach to Second Language Acquisition. In Dwight Atkinson (Ed.), Alternative Approaches to Second Language Acquisition (pp. 73-94). Routledge: Paperback,Kindle Edition.

[47] Murphey, Tim; Chen, Jin; \& Chen, Li-Chi (2005). Learners' constructions of identities and imagined communities. In P. Benson \& D. Nunan, (Eds.). Learners' Stories: Difference and Diversity in Language Learning. pp. 83-100. Cambridge: Cambridge University Press.

[48] Pavlenko, A., \& Norton, B. (2007). Imagined communities, identity and English language learning. In: Cummins, J. and C. Davison (Eds.), Kluwer Handbook of English Language Teaching (pp. 669680). Dordrecht, Netherlands: Springer. http://dx.doi.org/10.1007/ 978-0-387-46301-8 43

[49] Prensky, M.(2001). Digital Natives, Digital Immigrants Part 1. On the Horizon, 9 (5), p.1 - 6 http://dx.doi.org/10.1108/107481201 10424816
[50] Rajadurai, J. (2010). Malays Are Expected To Speak Malay: Community Ideologies, Language Use and the Negotiation of Identities. Journal of Language, Identity \& Education, 9 (2), 91106. http://dx.doi.org/10.1080/15348451003704776

[51] Warschauer, M. (2009). Digital literacy studies: Progress and prospects. In Baynham, M; Prinsloo, M. (Eds.), The Future of Literacy Studies (pp. 123-140). London: Palgrave Macmillan.

[52] Weedon, C. (1997).Feminist practice and poststructuralist theory (2nd ed.). London: Blackwell.

[53] Zhao, S., Grasmuck, S., \& Martin, J. (2008). Identity construction on Facebook: .

\section{AUTHORS}

Latisha Asmaak Shafie is with the Academy of Language Studies, Universiti Teknologi MARA Perlis, Malaysia. (ciklatisha@perlis.uitm.edu.my).

Aizan Yaacob is with UUM College of Arts and Sciences, Universiti Utara Malaysia. (e-mail: aizan904@uum.edu.my).

Paramjit Kaur A/P Karpal Singh is with UUM College of Arts and Sciences, Universiti Utara Malaysia.(e-mail:paramjit@uum.edu.my).

This work was supported in part by Universiti teknologi MARA Perlis and Universiti Utara Malaysia. Manuscript received 30 June 2015. Published as submitted by the authors 15 November 2015 . 